\title{
Lagrange (1736-1813): a life in mathematics
}

\author{
Luigi Pepe
}

Published online: 29 March 2014

(c) Centro P.RI.ST.EM, Università Commerciale Luigi Bocconi 2014

\begin{abstract}
We retrace the scientific biography of JosephLouis Lagrange, entirely dedicated to the study of mathematics, from the time when, still adolescent, he abandoned the studies of law which were a family tradition. His existence was divided almost equally into three periods: Turin (1736-1766) where he was born and composed his first fundamental memoirs on vibrating strings and the calculus of variations; Berlin (1766-1787) at the Academy of Frederick II of Prussia, where he published many works and drafted his Méchanique analitique; and Paris (1787-1813), during the time of the French Revolution and the Napoleonic Empire, where he published his treatises and received the highest honours. Here we present the few significant events of his private life and the many results with which he enriched almost all the mathematical sciences.
\end{abstract}

Keywords Lagrange · Biography · Turin · Paris · Berlin

Joseph-Louis Lagrange (Fig. 1) passed away quietly in Paris, assisted by his young wife, on 10 April 1813 (he was born in Turin on 25 January 1736). Napoleon, who had made him first Senator of the French Republic, and then Count of the Empire, and defined him as the haute pyramide des sciences mathématiques (the lofty pyramid of the mathematical sciences), ordered that he be commemorated in the territories of the French Empire and the confederate states. In Paris, Jean Baptiste Joseph Delambre (1749-1823) presented the eulogy at the Institute; in Turin the commemoration at the Academy of Sciences was given

L. Pepe $(\bowtie)$

Dipartimento di Matematica E Informatica, Università di

Ferrara, Via Machiavelli, 35, 44100 Ferrara, Italy

e-mail: luigi.pepe@unife.it by Anton Maria Vassalli Eandi (1761-1825); in Rome it was given by Gaspare Antonio Degregori (1768-1846), then president of the Court of Appeals; at the University of Padua it was given by Pietro Cossali (1748-1815). ${ }^{1}$

The most celebrated of these commemorations, Delambre's Notice sur la vie et les ouvrages de M. le Comte J. L. Lagrange, was reprinted in vol. 1 of the Oeuvres di Lagrange; the Prefect and Baron of the Empire Frédéric Maurice added a few notes and made several corrections. Of particular interest are his recollections, printed in $L e$ Moniteur Universel of 10 February 1814. The final part of Maurice's article is devoted to the famous Directions given by Lagrange for those wishing to learn mathematics. Maurice (Note de l'auteur de la Lettre) recalls that these confidences were made one evening after Lagrange had fenced, as he used to, and that they had remained impressed in his memory because it was the only time in which he had explained them in the 15 years of their acquaintance. These were the rules that Lagrange had set for himself:

1) He did not study more than one work at a time;

2) When he was not able to overcome a difficulty, he set it aside to take it up in a second moment;

3) He never put down a book that he had chosen without have completely assimilated it;

4) He never studied the great treatises of analysis, but rather limited himself to consulting them when necessary, lingering over them only when he found a new or intriguing method;

5) He always sought to understand the reason why the authors had followed one path or another;

\footnotetext{
1 The sole exception was the lack of a commemoration at the Berlin Academy. Prussia had begun a war against France, which would culminate in the Battle of Leipzig (October 1813).
} 


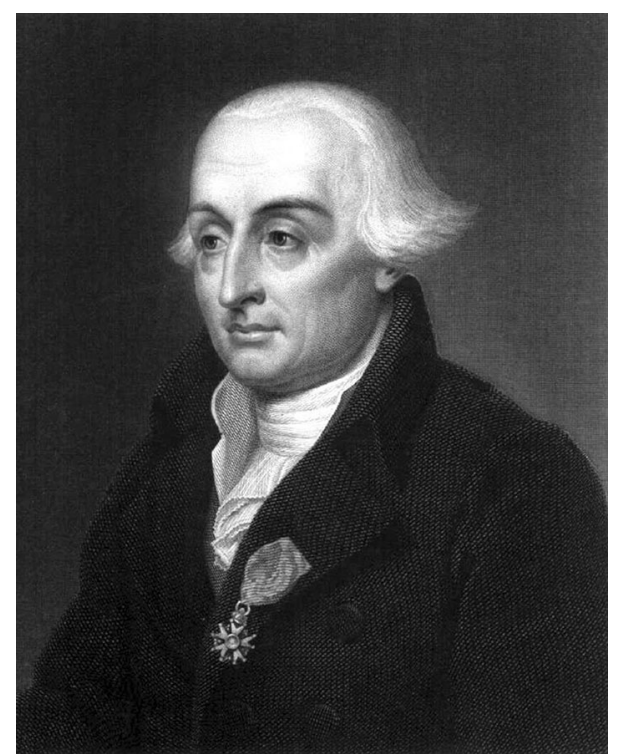

Fig. 1 Joseph-Louis Lagrange (1736-1813). From The Gallery of Portraits With Memoirs, vol. II (London: Charles Knight, 1833), p. 88

6) He read the works with pen in hand, redoing the calculations and practicing what he knew on the problems he encountered;

7) As far as possible, he tried to devise his own theories on essential points;

8) He was careful to return frequently to geometrical considerations that were well suited to giving power and cleanness to the reasoning;

9) He never finished working without having given himself a task for the following day: this, by the example of Frederick II of Prussia, to overcome his natural human laziness.

With regard to point (4), Lagrange added that after the first rudiments of differential and integral calculus he had begun to read Euler's Mechanica and had come to learn there not only dynamics but also integral calculus. He concluded by repeating the advice that he gave most often: to be a mathematician, it was necessary to study Euler.

Lagrange, having been directed towards his father's profession as an administrative functionary, and thus towards studies of law, had very early developed his interest in mathematics. "On his own and without a teacher" he read in $<2$ years, from 1752 to 1754, the Instituzioni analitiche by Maria Gaetana Agnesi of 1748; the Lectiones mathematicae de Calculo integralium by Johann Bernoulli, published in Opera in 1742; the Mechanica by Euler of 1736; the first two books of the Principia by Newton; the Traité de dynamique by d'Alembert of 1743; and the Traité du calcul intégral by Bougainville of 1752-1754, this last composed within the sphere of d'Alembert and the encyclopaedists.
In 1754 he undertook the study of Euler's 1744 monograph Methodus inveniendi lineas curvas maximi minimive proprietates gaudentes, which suggested to him-then only 19 years old-his first great mathematical discovery, which, communicated to Euler by letter in 1755, was baptised by him the "method of variations". This was a great technical improvement for solving problems of maxima and minima which involved an infinite number of variables, without proceeding, as Euler had done, by means of polygonal approximations. Lagrange's method then easily extended to several variables, and in fact he gave a first application of the equation of the surfaces of minimum area, which he communicated to Euler the following year, 1756. In the meantime, Lagrange had become assistant of mathematics in the Royal School of Artillery and Fortifications, founded to train the technical echelons of the army. To aid his teaching, he composed a short but important treatise on analytical geometry and differential and integral calculus: the Principi di analisi sublime, which remained unpublished for a long time. Meanwhile he continued to work on the applications of his method of variations, which he hoped to be able to print in Berlin with the support of Euler and Maupertuis. Maupertuis, president of the Berlin Academy, saw in the young Turinese mathematician, a new and brilliant champion of his principle of least action, on which he hoped to lay the foundations of all of mechanics. Lagrange's desire to publish a volume with the applications to mechanics of the method of variations remained frustrated because of the interruption of ties between Turin and Berlin by the 7 Years' War (1754-1763), and Maupertuis's return to France in 1757 and death in Switzerland in 1759.

Lagrange, together with two other young Piedmontese scientists, Giovanni Francesco Cigna and Giuseppe Angelo Saluzzo, had in the meantime created a "Private Society" (1757), which was to occupy itself (following the model of the Académie des sciences et belles lettres in Berlin) with natural philosophy, mathematics, astronomy and sciences, but also with theoretical philosophy, geography and history. This Private Society obtained the title "Royal Society" in 1760, and was then transformed in 1783 into the Royal Academy of Sciences, limiting itself, however, to mathematics and the experimental sciences. The Private Society had been successful in launching the publication of a series of volumes, initially named Miscellanea Taurinensia, modelled on the Miscellanea Berolinensia, which, under Leibniz's tutelage, had begun being printed in Berlin in 1710. The first volume of the Taurinensia appeared in 1759. As secretary, Cigna opened the Miscellanea Philosophico-Mathematica Societatis Privatae Taurinensis with a long survey (vol. I, pp. 1-51) of the experiments, carried out in collaboration among the members, entitled "De iis, quae in societate acta sunt Commentarii" (it should be 
noted that Lagrange as well took an active part in the research in experimental physics).

The first volume of the Miscellanea contained three memoirs by Lagrange, which constitute the best documentation of his scientific activity. The memoirs are entitled:

- Recherches sur la méthode de maximis et minimis (vol. II, pp. 18-32);

- Sur l'intégration d'une équation différentielle à différences finies, qui contient la théorie des suites récurrentes (vol. II, pp. 33-42);

- Recherches sur la nature et la propagation du son (vol. III, pp. 1-112).

The third of these is practically a monograph on the nature and propagation of sound, with which Lagrange intervened in one of the most debated questions of the day: the solution to the equation of vibrating strings, the subject of the research (and polemics) of d'Alembert, Euler and Daniel Bernoulli. The text of "Recherches sur la nature et la propagation du son" is divided into two sections. The first, entitled "Recherches sur la nature du son" comprises seven chapters: I. "Des oscillations des parties intimes des fluides élastiques"; II. "Des vibrations des cordes"; III. "Solution du problème général proposé dans les chapitres précédentes"; IV. "Analyse du cas ou le nombre des corps mobiles est fini"; V. "Analyse du cas ou le nombre des corps mobiles est infini"; VI. "Réflexions sur les calculs précédents"; VII. "Théorie des cordes de musique et des flutes". The second, entitled "De la propagation du son", is divided into three chapters: I. "De la vitesse du son"; II. "De la réflexion du son, ou des échos"; III. "Du mélange et du rapport des sons".

This memoir, which would be followed by a second memoir on the same topic, "Nouvelles Recherches sur la nature et la propagation du son" (published in the second volume of the Miscellanea for the years 1760-1761), is of fundamental importance not only for the study of a physical-mathematical problem that is quite relevant in itself, but above all because it constitutes, together with the works on the same topic by Daniel Bernoulli, d'Alembert and Euler, a fundamental chapter in the theory of expansion in trigonometric series that was already so important at the mid-eighteenth century and would continue to be, following the clarification of the concept of function, for the framework of the fundamental chapters of analysis. The "Recherches sur la nature et la propagation du son" is also exemplary, with regard to the presentation of the arguments, of improvements in the work of Lagrange. The exposition of the research is preceded by an accurate historical analysis of the works of other mathematicians who had brought the research in question forward to that time. In this case, the treatment begins with Newton's Principia Mathematica (Book II, section VII), not without citations of earlier authors, examines the results of Taylor, then discusses in detail the works of d'Alembert, Euler and Daniel Bernoulli. The historical references in the memoir are not limited to mathematics, but also take into account the treatises of music, with reference to Mersenne, Wallis Rameau, Sauveur, Euler, to the entry "Fondamental" in the Enciclopédie (signed by d'Alembert), and the treatise on music by Tartini.

The international distribution of the Miscellanea and the memoir on vibrating strings paved the way for Lagrange to new international relations, in particular with Daniel Bernoulli in Basel and d'Alembert in Paris. With d'Alembert he began a deep friendship, which was solidified in 1763 on the occasion of his trip to Paris; this is testified to by an entire volume of correspondence-Oeuvres, vol. XIII-, which constitutes one of the most superb documents of the century of Enlightenment. There we have them discussing numerous questions of science, but also those of a general nature, such as the suppression of the Jesuits and the competitions in the academies. The correspondence with d'Alembert is a primary source for the biography of Lagrange, so poor in external events. The correspondence ceased only with the death of d'Alembert in 1783.

With the new horizons that opened to Lagrange at the beginning of the 1760s, and the incentive of the prizes of the Paris Academy, a new area of research was born: celestial mechanics. This became absolutely the subject most frequently visited by Lagrange, whose interests had actually ranged from number theory to algebra, from analysis to mechanics. It was precisely on the occasion of a problem in celestial mechanics-the study of the libration of the moon-that Lagrange would introduce the principle of virtual velocity, from which he derived the principle of least action. The moon did not revolve about the earth with exactly the same face turned toward it: parts of the lunar surface are illuminated alternately (libration). The Paris Academy announced a competition for the study of this phenomenon, and Lagrange won the prize in 1764 . Once he returned to Turin from Paris, he was increasingly dissatisfied with the small stipend he received as assistant in the School of Artillery and Fortifications (750 Piedmontese lire). It was thus that he joyfully accepted the invitation of d'Alembert and Frederick II of Prussia to move to Berlin in 1766 to occupy the position in the Academy there left vacant by Euler, who wished to return to St. Petersburg.

The journey from Turin to Berlin was rather long: Lagrange stopped in Paris, then visited London, where he came into contact with the British mathematicians, and from there arrived in Hamburg by boat. He arrived in 
Berlin in late autumn 1766, and was installed in the Academy as director of the Class of Mathematics, taking lodgings in the very centrally located Unter den Linden. ${ }^{2}$

The Berlin period was the most fertile of all for his scientific activity: in some 20 years-from 1766 to 1787 he published some 80 memoirs not on in the proceedings of the Berlin Academy, but also in those of Paris and Turin. In Berlin, Lagrange also composed his first treatise Mechanique analitique, printed in Paris in 1788.

In the early part of the Berlin period, Lagrange was involved in two new fields of research: number theory and Diophantine equations, and the general theory of algebraic equations. The "Réflexions sur la résolution algebrique des équations" of 1770-1771, published in Oeuvres III, pp. 205-421, constitute a fundamental step in the history of algebra. The discipline, created by the Arabs to solve second-degree equations, had progressed during the Renaissance with the solution of third- and fourth-degree equations. With Viète and Descartes, it had been applied to geometry, essentially transforming itself into the art of manipulating literal expressions. With Lagrange, it returned to being primarily with the study of equations in an indeterminate. Beginning with the memoir by Lagrange, Ruffini proved, at the end of the century, the impossibility of a general solution in radicals to polynomial equations of degree five or higher, a proof later complete by Abel.

In 1772 in Berlin Lagrange published the memoir "Sur une nouvelle espèce de calcul relatif à la différentiation et à l'intégration des quantités variables", which anticipated the vast program of using the theory of analytic functions to free analysis from any consideration of infinitesimals or fluxions. In the same year, he published another fundamental memoir on the integration of first-order partial differential equations. In 1773 he published the memoir on the attraction of elliptical spheroids; in 1775 a fundamental memoir on the integration of linear equations of finite differences; an instrument essential for the treatment of the applications of mathematics to the calculation of probability, and more generally to the problems posed in the human sciences. In this order of ideas, Lagrange read before the Academy a memoir regarding the project for a fund to insure the pensions of widow; the paper was not published because of disagreements with the ministers of the King of Prussia, due to the study's conclusion that predicted the bankruptcy of the fund. This was the occasion for Lagrange to demonstrate another aspect of his character, which was totally alien to seeking opportunities for conflict, always ready to speak well of all, and ever willing to satisfy the requests made of him by political powers. In

\footnotetext{
$\overline{2}$ Shortly after his arrival, Lagrange married a cousin of his, Vittoria Conti, who he had come from Turin, where the two young people had previously been acquainted.
}

this case, to the protests of the minister, he replied firmly that he had not been employed to be at the ministers' orders, and that he did not hold himself obliged to wait on the ministers and offer illumination that they had not asked for, that it was their job to select the technical personnel who were competent to carry out the given task.

The days of the long Berlin period were quite routine. The mornings were dedicated to correspondence and reading. After lunch, he paid visits or strolled by himself at a brisk pace. At the end of the afternoon he returned to his study, and for $6 \mathrm{~h}$ devoted himself to his research, obtaining the great results that made him famous. He said that he had learned this regularity from the behaviour of the King of Prussia.

The deaths in 1783 of d'Alembert and of his wife Vittoria struck him profoundly, and when in 1786 Frederick II of Prussia also died-the patron who had assured him of the independence that he considered necessary-Lagrange began seriously to consider leaving Berlin. His thoughts were perceived by Count Mirabeau, the French envoy to Berlin, who saw to Lagrange's move to Paris and his nomination as "Pensionnaire vétérain" in the Paris Academy of Sciences, of which until that time he had been a foreign member. In Paris, where he established himself in June 1787, Lagrange came into contact once again with Laplace and Condorcet, with whom he was in correspondence, and the Abbé Marie, who oversaw the printing of the Mechanique analitique in Paris in 1788.

Lagrange was convinced that the mathematical sciences had by then arrived to a state of final perfection, achieved in a unifying way within the framework of the theory of functions: mechanics as well, thanks to his work, had become a part of analysis. As Newton had done a century earlier, Lagrange then sought a new field of research to undertake, and he found it in chemistry. This discipline was then in a phase, thanks to the work of Lavoisier and his collaborators, of extraordinary developments: Lagrange, Laplace and Monge contributed to placing the new science on solid quantitative bases. Lagrange, among other things, made a fundamental observation in the physiology of respiration, remarking that the exchange of oxygen and carbon dioxide did not take place solely in the lungs, since the chemical reaction was a producer of heat which, if that were the case, would have destroyed the organ.

Lagrange had arrived in Paris on the eve of the great French Revolution, which found many supporters in the circle of the Paris Academy, including Monge, Condorcet and Bailly (who was the first mayor of Paris). The Paris Academy, at the behest of the National Assembly, created a commission to oversee the unification of the system of weights and measure, and in October 1790 Lagrange was called to take part in it. The commission continued to work, under different names and with different members, even 
after the suppression of the Academy on 8 August 1793 . Lagrange took part in the work, which led to the creation of the decimal metric system based on a unit of measure, the metre, that corresponded to the forty-millionth part of the length of a terrestrial meridian. From this linear measurement, for which a temporary prototype was created, derived the unit of weight (the kilogram) and the capacity in volume of the containers of liquids (the litre). The unit of reference was subdivided into decimal parts and had decimal multiples. Lagrange played a decisive role in the acceptance of the decimal system. To those who suggested a duodecimal system (12 is divisible by $2,3,4,6 ; 10$ only by 2 and 5), he antagonistically proposed an undecimal system (11 is a prime number): his intention was to highlight the advantage of the system with respect to the subdivision in submultiples consistent with the immediate evaluation of the difference between two quantities. The metric system was adopted in France in 1795 and was definitively launched in 1799 with the participation of numerous European scientists, including the Italian Lorenzo Mascheroni, who arrived in Paris as a representative of the Cisalpine Republic. This was effectively what has been defined as the first international scientific congress.

In 1792 Lagrange married a second time, with Adelaide Lemonnier, daughter of the astronomer and academician Pierre Charles; he thus acquired the right to French citizenship. The marriage contract was signed by the French King, who was deposed immediately after, in August 1792, and thus the citizenship could not be claimed. In 1793 Lagrange risked expulsion from France because he was a citizen of Piedmont, a country at war with the French Republic. He was saved thanks to the intervention of various colleagues, and placed in requisition to study problems related to ballistics. When foreign enemies were defeated, and Robespierre's dictatorship had ended tragically, the Directory undertook reconstruction of the nation's cultural institutions. In 1794 was created the École Normale, charged with training future teachers for schools. In 1795 Lagrange gave his celebrated "Leçons élementaires sur les mathématiques" in which he also expounded his method of polynomial interpolations for functions. On 24 May 1795, Lagrange also held his first lessons at the École centrale des travaux publics (later the École Polytechnique). Out of his lessons, initially planned for the course in analysis applied to mechanics and which later became lessons of a general nature open to various attendees, grew his two important monographs: Théorie des fonctions analytiques of 1797 and Leçons sur le calcul des fonctions, the second edition of which was published in 1806.

On 25 June 1795, Lagrange was named (with Laplace) a member of the Bureau des longitudes, which took the place of the suppressed Observatory; on the following 27 December he was elected president of the first class of the
National Institute of Sciences and Arts, which substituted the former academies. He was by that time stably inserted into the scientific community and into the system of the great schools born of the Revolution.

In December 1798, in a Turin occupied by French troops, at the behest of Talleyrand, minister of foreign affairs for the Republic, there was a solemn ceremony in honour of Lagrange's father. For all of the Napoleonic period, the Turinese mathematician was a symbol of the ties between France and Piedmont. ${ }^{3}$

In Paris in 1799, following the coup d'etat of General Bonaparte, who became First Consul, was instituted the Sénat conservateur, and Lagrange became one of the first senators. It was Lagrange who proposed in 1802 the annexation of Piedmont to the French Republic. With the proclamation of the Empire, Lagrange found himself among the great dignitaries of state: as a senator, he was named in 1808 a count of the Empire, and later conferred with the Order of the Reunion (he was already a Grand Official of the Legion of Honour). Like Euler, Lagrange continued to carry out valid scientific work until the end of his days. He revised and republished his monographs on analytic functions, on the solution of numerical equations, on analytical mechanics (reprinted in two volumes in 1811 and 1815). From 1795 to 22 March 1813, he participated assiduously in the sessions of the Institute, reading various memoirs, such as the one on the method of variations of arbitrary constants, which opened new horizons in celestial mechanics, developed successively by Cauchy and Hamilton. Appreciated for his impartiality and his competence, the first works submitted to the Institute by Ampère, Poisson, Poinsot, Budan, Brunacci and Ruffini were subject to his judgment.

In March 1813, the state of his health worsened, and on 8 April he received a visit from Monge, Lacépède and Chaptal. Men often live as though they will never die, and die as though they had never lived: this was not the case of Lagrange, who entertained his visitors with a brief conversation in which he declared the content of his existence and prepared to die. He said that he had done things that were appreciated in the field of mathematics, and had obtained honours and recognitions. He was assisted by an attentive wife; life had to end; one must not fear death. He ceased to live 2 days later.

(Translated from the Italian by Kim Williams).

\footnotetext{
3 In that same year, Lagrange gathered his studies on algebraic equations in the monograph De la resolutione des équations numeriques de tous les degrés.
} 


\section{For further reading}

Author's note. Lagrange's biography has been the object of much attention, which however has been concentrated in a discontinuous fashion in the years of his death, in the years of the publication in Paris of his works (by Loria, Sarton, Burzio); see "Lagrange e i suoi biografi" (1993) in the list below. In the 1970s, the emergence of a substantial group of unpublished documents and letters made it possible to promote new studies on behalf of Maria Teresa Borgato and myself. What follows is an essential list of my works on Lagrange:

Pepe, L.: Lagrange e la trattatistica dell'analisi matematica. Symp. Math. 27, 69-99 (1986)

Pepe, L.: Tre "prime edizioni" ed un'introduzione inedita della Théorie des fonctions analytiques di Lagrange". Boll. Storia Sci. Mat. 6, 17-44 (1986)

Pepe, L.: Sull'edizione delle opere di Lagrange. In: Giusti, E. and Pepe, L. (eds.) Edizioni critiche e storia delle matematiche, pp. 109-122. ETS, Pisa (1986)

Pepe, L.: Angelo Genocchi e l'edizione della corrispondenza di Lagrange. In: Alberto Conte and Livia Giacardi, (eds.) Angelo Genocchi e i suoi interlocutori scientifici, pp. 221-240. Dep. Subalpina di Storia Patria, Turin (1991)

Pepe, L.: Supplemento alla bibliografia di Lagrange: I "Rapports" alla prima classe dell'Institut", Boll. Storia Sci. Mat. 12(2), 279-301 (1992)

Pepe, L.: Clifford Truesdell e la storia delle matematiche. Physis 29, 862-865 (1992)

Pepe, L.: Lagrange e i suoi biografi. Preface to F. Burzio, Lagrange, II edizione, Utet Libreria, pp. XI-XLIII (1993)

Pepe, L.: Quando Lagrange divenne cittadino francese? Archimede 47, 80-84 (1995)

Pepe, L.: La filosofia naturale nella formazione scientifica di Giuseppe Luigi Lagrange. Rivista di filosofia 87(1), 95-109 (1996)

Pepe, L.: Lagrange Giuseppe Luigi. In: Dizionario Biografico degli Italiani, Roma, Istituto dell'Enciclopedia Italiana 63, pp. 75-80 (2004)

Pepe, L.: Il giovane Lagrange e i fondamenti dell'analisi. In: Giannantonio Sacchi Landriani and Antonio Giorgilli (eds.) Sfogliando la Méchanique analitique, pp. 37-49 Edizioni Universitarie di Lettere Economia Diritto, Milan (2008)

Pepe, L.: Sulla via del rigore. I manuali di analisi matematica nell'Ottocento in Italia. In: Gian Paolo
Brizzi and Maria Gioia Tavoni, (eds.) Dalla pecia all'ebook. Libri per l'Università: stampa editoria circolazione e lettura, pp. 393-413. Clueb, Bologna (2009)

Pepe, L.: Matematica e matematici tra Italia e Isole britanniche (1815-1870). In: Luigi Pepe (ed.) Europa matematica e Risorgimento italiano, pp. 37-57. Clueb, Bologna (2012)

Pepe, L.: Lagrange, citoyen ou "sans papiers"? In: Suzanne Féry (ed.) Aventures de l'analyse de Fermat à Borel. Mélanges en l'honneur de Christian Gilain, Nancy, Pun Editions Universitaires de Lorraine, pp. 473-481 (2012)

Pepe, L. and Borgato, M. T.: Lagrange a Torino (1750-1759) e le sue lezioni inedite nelle R. Scuole di Artiglieria”, Boll. Storia Sci. Mat. 7(2), 3-43 (1987)

Pepe, L. and Borgato, M. T.: Una memoria inedita di Lagrange sulla teoria delle parallele. Boll. Storia Sci. Mat. 8(2),307-335 (1988)

Pepe, L. and Borgato M. T.: Sulle lettere familiari di Giuseppe Luigi Lagrange”, Boll. Storia Sci. Mat. 9, pp. 193-318 (1989)

Pepe, L. and Borgato, M. T.: Lagrange, appunti per una biografia scientifica, Turin, La Rosa (1990)

Pepe, L. and Borgato, M. T.: L'inventaire des manuscrits de Lagrange et la mécanique avec l'édition du manuscrit de Lagrange "Differentes notes sur les ouvrages de mecanique". Atti Acc. sci. Torino Cl. sci. fis. mat. nat., (suppl.) 124, pp. 25-49 (1990)

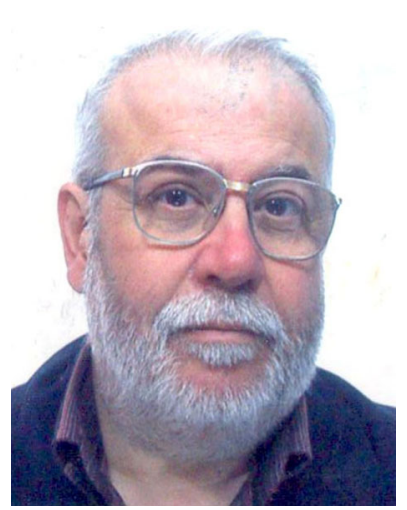

Luigi Pepe is full professor at the University of Ferrara. He joins an interest in the history of the mathematical sciences with that of this history of scientific institutions. He is the author of more than 200 publications, including some 20 monographs dedicated to Copernicus, Lagrange, Monge, and the national institutes of Napoleonic Europe. His is the secretary of the committee for the publication of the collected works of Gaetano Salvemini, a corresponding member of the Académie Internationale d'Histoire des Sciences, and president of the Società Italiana di Storia delle Matematiche. 